Yuryi PRYSYAZHNYUK

Ivan Franko National University of Lviv, Faculty of International Relations, Ukraine

Romana MIKHEL

Lviv Institute of Economy and Tourism, Accounting and Economics Faculty, Ukraine

\title{
Models of Economic Space Ecologization Under the Conditions of Sustainable Development
}

\section{Modele ekologizacji gospodarki w warunkach zrównoważonego rozwoju}

\section{- Abstrakt •}

W artykule rozpatrywane jest zagadnienie globalnej przestrzeni gospodarki w kontekście jej ekologizacji. W świetle współczesnej koncepcji zrównoważonego rozwoju szczególnie ważne wydaje się badanie teoretycznych i praktycznych aspektów procesu ekologizacji systemu gospodarczego, co stało się celem niniejszego artykułu. Zarysowano w nim podstawowe zasady funkcjonowania i współistnienia systemów ekologicznego i gospodarczego, zaprezentowano też główne modele modernizacji stanu środowiska w perspektywie gospodarczej (zwłaszcza modele zrównoważonej produkcji i konsumpcji). Autorzy skupiają się na koncepcji „zielonego wzrostu” i uogólnieniu analitycznych podstaw opartej na nim strategii, w szczególności uwzględniając warunki i narzędzia wytwarzane na poziomie polityki państwowej. W konkluzji autorzy szkicu uwypuklają ważne i priorytetowe obszary ekologizacji w rozwoju społeczno-gospodarczym.

\section{- Abstract •}

The article concerns the problems of the global economic space in terms of its ecologization. In the conditions set by the modern concept of sustainable development, an important task is to study the theoretical and practical aspects of the process of the economic system ecologization, which is the purpose of this study. The article outlines the basic principles of the functioning and co-existence of the ecological and economic systems, presents the main models of environmental modernization of the economy (in particular, the models of sustainable consumption and production). The authors focus on the concept of "green growth" and generalize the analytical basis of the green growth strategy, in particular the necessary conditions and instruments of the state policy. Summing up, the authors highlight important and priority areas of ecologization of the economic development of society. 
Słowa kluczowe: ekologizacja; system gospodarczy; zrównoważona konsumpcja i produkcja; „zielony wzrost”
Keywords: ecologization; economic system; sustainable consumption and production; "green growth"

\section{Introduction}

In the modern-world economic space, international environmental safety becomes a particularly critical and actual issue. It is characterized by a new dimension and global significance, i.e. the implementation of sustainable development strategies, which foreshadows the creation of a progressive model of economic growth. It takes into account the principles of "fairness" of preservation and distribution of ecological resources for the secure development of humanity's present and future.

In the respect of the mentioned changes caused by the development of ecologization processes in the world economy, we can distinguish the following fundamental trends:

- The shift of the ecology towards being the focus of global discussions;

- Qualitative changes in the technological basis of the economy: ecotechnologies become the leading link to scientific and technological progress;

- Implementation of new criteria and indicators of socio-economic development: from the gross output measurement to the qualitative characteristics of the environment;

- A radical reorganization of the institutional system of the economy, taking into account the critical importance of environmental risks and challenges;

- Socio-economic and political implications of environmental modernization.

All of the above-mentioned changes confirm the significance of researches that are held in the field of ecologization of the economic system. Thus, the purpose of the article is to study the theoretical and practical aspects of the ecologization process of the economic system in the context of the global challenges of sustainable development.

\section{Definitions}

The origin of ecological problems studies and their connection with economic development can be found in the classical economic school studies. In particular, the representatives of the classical economic school (Ricardo, Malthus, Marx) investigated important and actual aspects of the use of natural resources. Within 
the framework of this approach, the forces of nature are considered as a resource that, under competitive conditions of management, will decrease, what in turn will lead to the deterioration of the economic environment of future generations (Antologiya ekonomicheskoy klassiki, 1991).

The representatives of the neoclassical economic school (Marshall, Pigou) based their approach on the theory of a market economy. The main emphasis the representatives of this school laid was on the limited resources, including natural ones (e.g., lands, reducing their fertility) (Pigou, 1920). In the framework of this theory (based on the theory of "external effects"), the introduction of taxation on the usage of natural resources and payments for pollution were proposed.

One of the first modern theoretical and methodological approaches to the study of ecologization of the economy is the 'noosphere' concept of sustainable development, the founder of which is the Ukrainian scientist Vernadsky. The basic principle of this concept is the principle of unity and close interrelation of man and his environment. According to Vernadsky (1977) and his followers, sustainable socio-ecological and economic development must be controlled by humanity - otherwise the bifurcation mechanism may evolve in a completely unpredictable direction and eventually lead to the death of the humanity.

On the international stage, the beginning of cooperation in the field of ecology is connected with the creation of the Club of Rome in 1968 by the Italian economist Aurelio Peccei. It was an international non-governmental organization, which proclaimed the need for active cooperation in the fight against environmental pollution. In the 1980s, it became clear that solving global and national environmental problems was impossible without a new look at the role and forms of economic development. That was the time when the idea of transition of the economic development to the concept of sustainable development was formed and it was first fully described in the World Conservation Strategy (1980).

In the last quarter of the twentieth century, in the developed countries there were elaborated different approaches to understanding the concept of the environmental economy. Among the concepts that reveal the ways to achieve the goals of sustainable development (along with the concepts of "green economy", "clean production", "eco-intensity", etc.) is the concept of ecological modernization. It, in turn, includes the concept of ecologization of economic development (Omel'chenko, Obykhod, \& Nechytaylo, 2016). Ecologization of the economy is a multidimensional phenomenon that affects the problems of economic, industrial and social nature; it is also a necessary condition and at the same time the main component of environmentally balanced development. This issue has been revealed by such researchers as Deyli (2002), Ikerd (2012), Schneider, Kallis, \& Martinez-Al- 
ier (2010), Stavins, Wagner, \& Wagner (2003), etc. The latest works define the ecologization of economics as aggregated relations between the state, society and enterprises that arise for the sake of ensuring sustainable harmonization of interests of the economy and ecology, and are aimed at reducing the socio-economic costs of economic activity by ensuring the elimination of the negative effects of the intensive usage of natural resources.

\section{The Principles of Sustainable Functioning of the Ecological and Economic System}

In the context of global challenges, the ecologization of the economy and the transition of the mankind's entire system of economic reproduction to principles consistent with the objectives of environmental protection, are crucial conditions for the sustainable development of a particular country and global economy as a whole and for an increase in the effectiveness of the mechanism of international economic relations.

Ikerd (2012) highlights the basic environmental principles of a sustainable economy. These are holism, diversity, and interdependence. The principle of holism can be summarized with a simple statement: "a whole is bigger than the parts that make it up". The whole possesses properties that arise only when its parts coalesce into a holistic organism.

Diversity grants living systems an ability to renew and rebirth. It allows them to live, grow, mature, produce, reproduce, and develop. Diversity provides the sustainability needed to withstand unforeseen threats to health or life, such as physical attacks and illnesses, and recover from them.

Interdependence serves as a reward or gaining for respecting the principles of holism and diversity. In interconnected systems, the output of one process becomes an input for another. One species' waste serves as a resource for the other. Interdependence allows control over the decentralization of natural ecosystems.

According to Ikerd (2012), an ecological (real) view on the economy puts it in a hierarchy where it is embedded in society while society functions within nature. In such a hierarchical framework, decisions are made at the highest level of the organization while lower levels determine the opportunities. Consequently, the purpose of society derives from nature, and the purpose of the economy stems from society. The opportunities of society are influenced by the economy while the opportunities of nature are defined by society. Ikerd argues that the most important mission of sustainable development is to improve the quality of life. A sustain- 
able economy has to be managed and regulated to create and restore the resources needed to enhance the social and environmental qualities (which are required to support the economy as well as the desired quality of life).

Thus, the sustainability of economic development provides the economy with the stable output (final) parameters of the productive, social and economic development indicators.

The purpose of state economic policy is to achieve internal and external stability of the system. At the same time, internal stability implies a state of the economy characterized by steady production, prices, employment and supporting a certain standard of living. The external stability of the system should be understood as the sustainability of the balance of payments, positive foreign economic balance, and stability of the gold reserves. At the same time, at this stage, the tools of the economic policy include budgetary, financial, tax, price, and foreign trade elements. Using and combining those tools, a state can achieve the goals set before it (Dokholyan, 2011). To achieve sustainable development, the world economy should switch to sustainable production and consumption model. Such a transition is directly related to the state of the ecosystem at regional and global levels.

\section{The Model of Sustainable Production and Consumption in Modern Economic Space}

The transition to sustainable consumption and production model should be implemented to promote the socio-economic development of the state and should not reach beyond the assimilative potential of ecosystems. Such a transition envisages dilution and (if appropriate) elimination of the correlation between economic growth and environmental degradation. The latter is conducted via improving efficiency and ensuring the sustainability of resources use and production processes, as well as reducing the extent of resource degradation, pollution and tolls (United Nations, 2002).

In the modern world (in the context of limited resource availability in particular), creating sustainable consumption and production model is one of the main requirements of sustainable development (as highlighted by the "Rio +20 " and the summit of the High-Level Expert Group (HLEG) on developing agenda for the post-2015 period). HLEG also noted that the goals formulated in the Proclamation of the Millennium Development Goals do not address the principal objective of creating sustainable consumption and production models. A number of governments (within the framework of the Open-Ended Working Group on Sustainable 
Development Program Goals SDG) recognized that this goal should be included in the SDG program either as an independent objective or as a common goal for other purposes regarding food security, health protection, economic growth, industrialization, urbanization, and ecosystems (UNEP, 2014).

Sustainable consumption and production represent a holistic approach to systemic changes. This approach is based on three major goals:

- Separating environmental degradation and economic growth. It means producing better and more goods and services (while increasing net profit from the economic activity) by reducing the use of resources and pollution throughout the entire product life-cycle;

- Application of the "life-cycle" way of thinking. The essence of this objective is to increase sustainable resource management and to achieve the efficiency of the resources used in the phases of production and consumption of the product life-cycle (e.g., resource extraction, interim materials production, distribution, marketing, use, recycling and reuse of products and services);

- Identification of opportunities for developing and "leapfrogging" countries. Sustainable consumption and production contribute to the eradication of poverty and the achievement of the United Nations Millennium Development Goals (MDGs). Sustainable consumption and production offer the developing countries opportunities such as creating new markets, "green" jobs and decent workplaces, as well as more efficient welfare management of natural resources. Such actions allow states to "leap over" to more sustainable, environmentally friendly and competitive technologies (UNEP, 2015).

Ensuring a more sustainable, clean and efficient production of goods and services is essential for sustainable development (Goal 12, 2019). Aspects of the SDG related to supply require the solutions to the following tasks: 1) sustainable provision of natural resources required for the survival of people, such as water, food, electricity, as well as resources suitable for agricultural activities and housing; 2) sustainable support for production factors of economic development involves the assessment and balanced management of major renewable and non-renewable resources (e.g., fuelwood, metals and minerals); and 3) reducing human and economic pollution, including emissions of greenhouse gases, toxic chemicals, particulates and excess emissions of nutrients that could be detrimental to human health or cause degradation of ecosystems.

With current tendencies, by 2050, the world's population might come to 9.5 billion and the middle class (which is currently growing worldwide) might reach 3 billion people (United Nations, 2018). Meanwhile, it is important to understand that sustainable consumption does not necessarily mean better (more efficient) 
consumption, constituting a lower risk for our health and the environment. Sustainable consumption involves changes in consumer behaviour and all kinds of people-infrastructure interactions (mobility, leisure, housing). Those, while combined, shape our very lifestyle. Sustainable consumption requires the convergence of current consumption patterns, emphasizing the need for more responsible consumption. This can be fostered through a range of political, economic and voluntary measures, including formal and informal education. In addition to reduced environmental risks and expanded opportunities due to environmental advances, sustainable consumption can generate economic benefits and increase social welfare (access to markets, innovation, more workplaces, and healthier lifestyle).

\section{Concept of "Green Growth" as a Mean towards Achieving Harmony between the Ecological and Economic System}

A sustainable model of production and consumption certainly is closely connected to the concept of "green growth". It aims to stimulate economic development and facilitate human welfare through the preservation and rational use of natural capital (UNEP, 2014). In other words, the natural resources and ecosystems that provide raw materials, energy, water and diverse ecosystem services affecting the welfare of states.

The concept of green growth was first introduced in Seoul, in 2005. It took place at the Conference of the Ministers of the Environment of the Asia-Pacific Region (UNDESA, 2013). Subsequently, in the midst of the global economic downturn in 2009, this idea came to the continuation in "A Global Green New Deal" concept, suggested by the United Nations Environment Programme (UNEP). In 2011, UNEP developed an approach to assessing the green growth progress, presented in the Green Growth Survey: Progress Report. It describes a conceptual measurement methodology integrating the basic parameters of green growth with the basic accounting principles and the pressure-state-reaction model, which is applied to environmental reporting and expertise.

Lately, in 2011, 25-30 indicators of green growth were selected by the Organisation for Economic Cooperation and Development (OECD, 2011). These are divided into four major groups: ecological and resource efficiency of the economy; the base of natural assets; environmental aspects of quality of life; economic opportunities and political tools related to green growth. In addition to these four groups, indicators have been identified that reflect the socio-economic context and growth parameters. 
The main elements of any green growth strategy are two vast sets of political measures. The first set consists of the framework policy measures, mutually reinforcing economic growth and preserving natural capital. Among these are the major tax and regulatory measures such as taxation and competition. Innovative political measures should also be added to this set. The second set includes political measures stimulating the effective use of natural resources and leading to increased financial costs associated with pollution. These include the combination of price-based tools, such as environmental taxes and non-market instruments such as regulations and technology support policies (OECD, 2014).

Thus, drawing from the UNEP and OECD concepts of green growth, we can summarize below the green growth strategy from an economic point of view (see: Figure 1).

Figure 1. Analytical Basis of the Green Growth Strategy

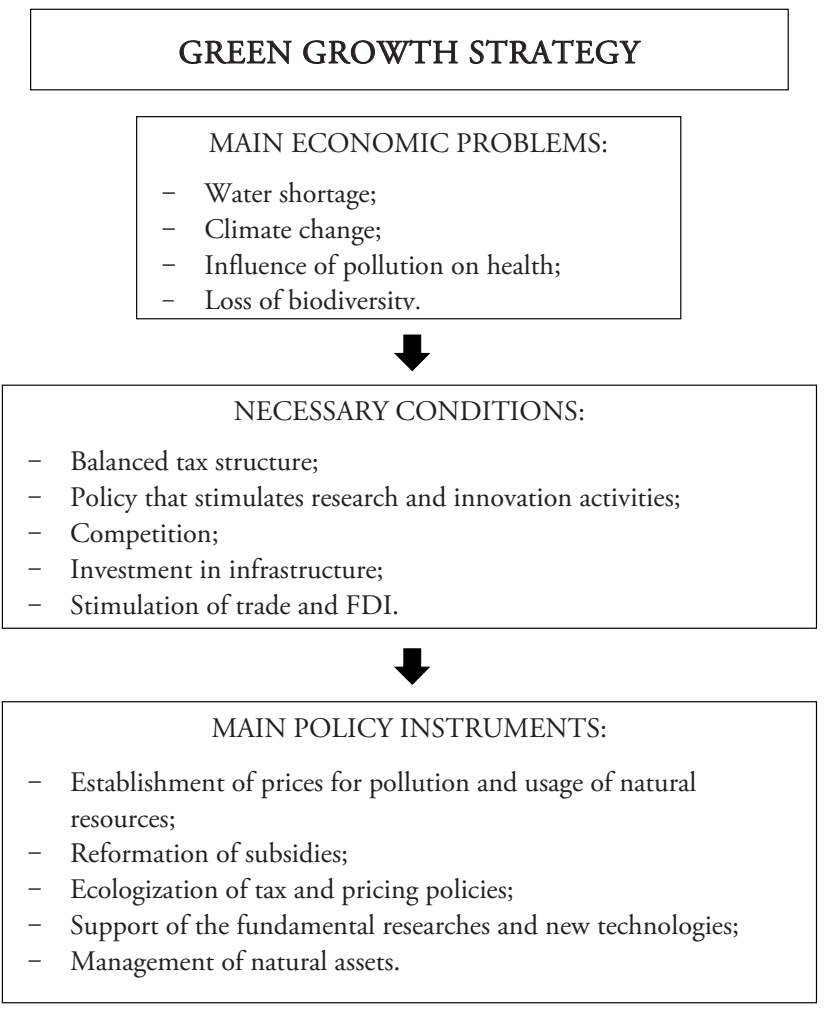

Source: authors' elaboration. 
Thus, apart from strengthening ecosystems, improving the environmental quality of life and sustainability of agricultural systems, the green growth policy offers several economic advantages and benefits (UNIDO and OECD, 2018). These include the following:

- Increased efficiency of production processes and creating new improved products;

- Innovations and structural changes in the economy, leading to the emergence of new sectors, products, services and business opportunities, as well as the elimination of the technological bottleneck problem, in particular in infrastructure sphere;

- Financial consolidation caused by the revision of the state-public spending composition and effectiveness and due to increased revenues at the expense of adequate pollution charges;

- Building up investors' trust thanks to greater predictability and stability of government policy regarding the key development and environmental issues;

- Balanced macroeconomic conditions and stabilization of resource costs.

Integration of these considerations into state policy lays the basis for green growth. Its goals are relevant to all countries yet its policies and approaches (designed to consolidate this model in day-to-day life) have to be adjusted to regional and national specificity and the countries' level of development.

However, while implementing the green growth concept, states might face several issues. In particular, a lack of demand for green innovation, inadequate funding or regulatory barriers surrounding new businesses, gaps and contradictions in the legislative frameworks as well as lack of overarching and targeted policies fostering green economy transition (Eap Green, 2016). To overcome these obstacles the states must act and regulate demand (e.g., public procurement, implementation of standards and regulations in specific markets and under specific conditions); consider the introduction of technology awards or subsidies; ensure access to financing (in particular, small and medium businesses). In this term the strong cooperation between the states and environmental organization (such as UNEP, EaP Green) is encouraged (EaP Green, 2017).

To achieve vast support for its policy, green growth has to address the issue of equality and justice from the very beginning. Green growth should offer effective solutions that offset the negative social consequences caused by certain state measures (e.g., the reform of the energy subsidies that are detrimental to the environment). 


\section{Conclusions}

Concluding, it is worth highlighting several important and priority directions of ecologization of economic development: 1) ecologization of the legislative base (orientation of legislative and normative documents on the environmental problems and their prevention, as well as the verification the environmental consequences for the state and population while adopting of one or another law in any field); 2) ecologization of the tax system on the basis of the approved legislation (the approval of taxes and tax rates in such way that it is more profitable for the producer to reorient their activities to environmentally safe production than to pay fines); 3) ecologization of industrial processes (the introduction of environmentally friendly production in all sectors of the national economy); 4) formation of the ecological consciousness of society, as well as environmental education.

A significant role in the process of ecologization is played by the coordination of technical, technological, organizational and economic innovations in the resource and ecological sphere. The introduction of innovative scientific and technological solutions in these spheres as well as the development of knowledge-intensive industries will contribute not only to production modernization, but also to combination of its interests with environmental protection and society development. The models of sustainable production and consumption, along with the concept of "green growth", are the basis for building a sustainable global economic system. Sustainable consumption and production are aimed at "doing more and better with lesser means", increasing the net benefit of economic activity for maintaining welfare by reducing the use of resources, reducing degradation and pollution throughout the life cycle, while at the same time improving the quality of life. This requires the participation of various stakeholders, including entrepreneurs, consumers, politicians, researchers, scientists, retailers, media, cooperation institutions, and others.

Thus, it can be argued that socio-economic sustainable development cannot be ensured without environmentally sustainable development. This means that the socio-economic development of society should respond to the environmental objectives. Only in this case, human development in all its manifestations will indeed be persistent. Thus, today the content of the concept of sustainable development has changed in the direction of ecologization of international relations in general and international economic relations, in particular.

Further researches can be devoted to the problems of environmental modernization of the economic system, both at the global and regional levels. 


\section{References:}

Deyli, H. (2002). Poza zrostannyam. Ekonomichna teoriya staloho rozvytku. Kyyiv: Intelsfera. Dokholyan, A. (2011). Problemy ustoychyvoho razvytyya ékonomyky rehyona. Sovremennye problemy nauky y obrazovanyya, 5. Retrieved from: https:/www.science-education. $\mathrm{ru} / \mathrm{ru} / \mathrm{article} / \mathrm{view}$ ?id=4975.

EaP Green (2016). Measuring the Green Transformation of the Economy: Guide for EU Eastern Partnership Countries. Partnership for Environment and Growth, Paris. Retrieved from: http://www.green-economies-eap.org/resources/EaP\%20GREEN_GGI\%20 Guide_clean_ENG_FINAL.pdf.

EaP Green (2017). Greening Economies in the EU Eastern Neighbourhood. From Commitment to Results. Partnership for Environment and Growth, Paris. Retrieved from: http://www.green-economies-eap.org/resources/EaPGREEN_BR_UPDATE_2017_ FINAL_WEB.pdf.

Goal 12: Ensure Sustainable Consumption and Production Patterns (2019). United Nations. Retrieved from: https:/www.un.org/sustainabledevelopment/sustainable-consumption-production/.

Ikerd, J. (2012). The Essentials of Economic Sustainability. Sterling, Virginia: Kumarian Press.

OECD (2011). Towards Green Growth. Organisation for Economic Cooperation and Development, Paris. Retrieved from: https://read.oecd-ilibrary.org/environment/towards-green-growth/summary/english_9789264111318-sum-en\#page7. DOI: https:// doi.org/10.1787/9789264111318-sum-en.

OECD (2014). Green Growth Indicators 2014. Organisation for Economic Cooperation and Development, Paris. Retrieved from: https://read.oecd-ilibrary.org/environment/ green-growth-indicators-2013_9789264202030-en\#page1. DOI: https:/dx.doi.org/ 10.1787/9789264202030-en.

Omel'chenko, A., Obykhod, H., \& Nechytaylo, T. (2016). Ekolohizatsiya ekonomichnoho rozvytku yak faktor modernizatsiyi vyrobnytstva. Ekonomist, 6, 24-27.

Pigou, A.C. (1920). The Economics of Welfare. London: Macmillan and Co.

Stavins, R.N., Wagner, A.F., \& Wagner, G. (2003). Interpreting Sustainability in Economic Terms: Dynamic Efficiency Plus Intergenerational Equity. Economics Letters, 79(3), 339-343. DOI: https://doi.org/10.1016/S0165-1765(03)00036-3.

Schneider, F., Kallis, G., \& Martinez-Alier, J. (2010). Crisis or Opportunity? Economic Degrowth for Social Equity and Ecological Sustainability. Introduction to this Special Issue. Journal of Cleaner Production, 18(6), 511-518. DOI: https://doi.org/10.1016/j. jclepro.2010.01.014.

UNDESA (2013). A Guidebook to the Green Economy. Issue 4: A Guide to International Green Economy Initiatives. United Nations Division for Sustainable Development. Retrieved from: https://sustainabledevelopment.un.org/content/documents/916guidebook4.pdf.

UNEP (2014). Sustainable Consumption and Production (SCP). Targets \& Indicators and the SDGs. UNEP Post-2015 Discussion Paper 2. United Nations Environment Programme. Retrieved from: https://www.iisd.org/sites/default/files/publications/scp_targets_indicators_unep.pdf. 
UNEP (2015). Sustainable Consumption and Production. A Handbook for Policymakers. United Nations Environment Programme. Retrieved from: https://sustainabledevelopment.un.org/content/documents/1951Sustainable\%20Consumption.pdf.

UNIDO and OECD (2018). Financing Resource Efficient and Cleaner Production by SMEs in the EU Eastern Partnership Countries: A Stakeholders' Guidebook. EaP GREEN Publication. Retrieved from: http:/www.green-economies-eap.org/resources/Stakeholders\%20Guidebook\%20for\%20RECP\%20finance $\% 20$ in\%20EaP.FINAL.pdf.

United Nations (2002). Plan of Implementation of the World Summit on Sustainable Development. A/CONF.199/20, Chapter I, Resolution 2 (pp. 6-72). United Nations, Johannesburg. Retrieved from: https://www.un.org/ru/events/pastevents/pdf/plan_ wssd.pdf.

United Nations (2018). Sustainable Consumption and Production Policies. Retrieved from: https://www.unenvironment.org/ru/node/1665.

Vernadskyy, V.Y. (1977). Razmyshlenyya naturalysta (v 2-kh kn.). Moskva: Nauchnaya mysl' kak planetarnoe yavlenye. 